\title{
ASPHALT MIXTURES WITH LIMESTONE AGGREGATE FOR BASE LAYER
}

Carmen Răcănel, Assoc.Prof.PhD.eng., Technical University of Civil Engineering Bucharest, The Faculty of Railways, Roads and Bridges, e-mail: carmen@cfdp.utcb.ro Mihai Dicu, Prof.PhD.eng., Technical University of Civil Engineering Bucharest, The Faculty of Railways, Roads and Bridges, e-mail: mdicu @ cfdp.utcb.ro

Ştefan Marian Lazăr, Lecturer PhD.eng., Technical University of Civil Engineering Bucharest, The Faculty of Railways, Roads and Bridges, e-mail: lazar@cfdp.utcb.ro Adrian Burlacu, Assistant PhD.eng., Technical University of Civil Engineering Bucharest, The Faculty of Railways, Roads and Bridges, e-mail: adrian_burlacu@yahoo.com

\section{Abstract}

Asphalt mixtures are mixtures of mineral aggregates, filler, bitumen and eventually additives in proportions determined by recipe designed in the laboratory. Asphalt mixtures used as base course are bituminous concrete.

The natural aggregates are granular materials of mineral origin that come from natural or artificial crushing of the rocks. In our country there are the various rocks: eruptive or magmatic rocks, metamorphic rocks, sedimentary rocks.

To the category of sedimentary rocks belong limestone. Sedimentary rocks are characterized by relatively high porosity and a pronounced stratification, which causes mechanical resistance to be low and vary by direction of load. Due to the structure less dense and weaker mechanical resistance, the limestone are used less in heavy traffic pavement structures.

This paper presents an asphalt mixture recipe for the base layer developed in the Laboratory of Roads from Technical University of Civil Engineering Bucharest (TUCEB), using limestone aggregates extracted from Hoghiz Quarry. The paper contains laboratory test results to determine the recipe and laboratory findings leading to the schedule of product.

Keywords: limestone aggregates, asphalt mixture, Marshall, module of stiffness, creep, fatigue

\section{Résumé}

Mélanges asphaltiques sont des mélanges de granulats minéraux, de charge, du bitume et éventuellement des additifs, dans certaines proportions déterminées par la recette conçue au laboratoire. Mélanges d'asphalte utilisés comme couche de base sont les enrobé bitumineux.

Les granulats naturels sont des matériaux granuleux d'origine minérale qui proviennent de naturel ou artificiel concassage des roches. Dans notre pays, il ya les 


\section{ROMANIAN JOURNAL \\ OF TRANSPORT INFRASTRUCTURE}

Carmen Răcănel, Mihai Dicu, Ştefan Marian Lazăr, Adrian Burlacu, Asphalt mixtures with limestone aggregate for base layer

différentes roches: roches éruptives ou magmatiques, roches métamorphiques, roches sédimentaires.

Dans la catégorie des roches sédimentaires calcaires appartiennent. Les roches sédimentaires se sont caractérisés par une faible porosité élevée et une stratification prononcée, ce qui provoque la résistance mécanique est faible et varie en direction de la charge. En raison de la structure moins dense et plus faibles résistance mécanique, les calcaires sont moins utilisés dans les structures de chaussées du trafic routier lourdes.

Cet article présente une recette de mélange d'asphalte pour la couche de base développé au Laboratoire des Routes de l'Université Technique de Génie Civil de Bucarest (UTGCB), en utilisant des granulats calcaires extraites de la Carrière Hoghiz. Le document contient les résultats des tests de laboratoire pour déterminer la recette et les résultats de laboratoire conduisant à l'annexe de produit.

Mots-clés: granulats calcaires, le mélange d'asphalte, Marshall, module de rigidité, de fluage, fatigue

\section{INTRODUCTION}

The natural aggregates are granular materials of mineral origin that come from natural or artificial crushing of the rocks and forms the mineral skeleton of the layer from pavement structure.

In our country due to geographical configuration, with mountains, hills, river basins, the quarry or ballast natural aggregates exploitations are numerous and widespread in all the geographical areas.

In our country there are the various rocks: eruptive or magmatic rocks, metamorphic rocks, sedimentary rocks. These rock types differ among themselves by the dialing mode, mineralogical composition, structure and their texture. Among these rocks, the eruptive are the most resistant and durable due to high silicates content. Highly hard rock, with densities and very high mechanical strength are also metamorphic rocks.

Of sedimentary rocks category are limestone that are rocks of organic origin, formed by the accumulation of skeletons and remains of plants and animals deposited and mineralized in water. Sedimentary rocks are characterized by relatively high porosity and a pronounced stratification, which causes mechanical resistance to be low and vary by direction of load.

Limestones have very different physical and mechanical qualities and their use in road works is made in relation to these qualities. Due to the structure less dense and weaker mechanical resistance, the limestone are used less in heavy traffic pavement structures. 


\section{PURPOSE OF THE PAPER}

This paper presents laboratory research conducted to study the possibility of using limestone aggregates in asphalt mixtures in the base layer.

The base layer is known to be located just below the clothing and is the most important layer to be made of durable material able to take over the traffic loads. It must be able to take over shear and tensile efforts and to transmit vertical unitary efforts to the foundation layers.

According to the romanian standard STAS 6400, base layers are made of: macadam, penetrated or semi-penetrated macadam, crushed stone stuffed with bitumen split, natural aggregates stabilized with hydraulic or pozzolanic binders, asphalt mixtures, cement concrete.

Among these materials in this paper we will refer to the base layer from asphalt mixtures. Asphalt mixtures are mixtures of mineral aggregates, filler, bitumen and eventually additives in proportions determined by recipe designed in the laboratory. Asphalt mixtures used as base course are bituminous concrete and are prepared to warm from natural aggregates, filler and non-paraffin bitumen for roads (pure bitumen) as SR 7970.

Of the two types of asphalt mixtures for base layer, was chosen in this paper to design a recipe of $\mathrm{AB} 2$ type asphalt mixture in the Laboratory of Roads from TUCEB.

\section{STUDY ON AGGREGATES}

In order to determine the possibility of achieving an asphalt mixture recipe for the base layer from pavement structure, were necessary laboratory determinations on component materials (aggregates from Hoghiz quarry) both as the european standard also adopted in our country, SR EN 13043 as well as the romanian standard, SR 667: granulometry, fine particle content, the quality of fine particles, shape of coarse aggregate, coarse aggregate fragmentation resistance, wear resistance, granules volumic mass, water absorption, resistance to freeze/thaw, Los Angeles resistance, crushing resistance by dry compression, resistance to repeated action of sodium sulphate, activity coefficient.

The results obtained are summarized in Table 1 and Table 2 . 
ROMANIAN JOURNAL

\section{OF TRANSPORT INFRASTRUCTURE}

Carmen Răcănel, Mihai Dicu, Ştefan Marian Lazăr, Adrian Burlacu, Asphalt mixtures with limestone aggregate for base layer

Table 1. Characteristics of aggregates according to SR EN 13043

\begin{tabular}{|c|c|c|}
\hline $\begin{array}{l}\text { No. } \\
\text { crt. }\end{array}$ & Characteristic & Category \\
\hline 1. & $\begin{array}{l}\text { granulometry: } \\
\text { - sort } 16 / 25 \\
\text { - sort } 8 / 16 \\
\text { - sort } 4 / 8 \\
\text { - sort } 0 / 4 \text { crushed sand } \\
\text { - sort } 0 / 4 \text { natural sand }\end{array}$ & $\begin{array}{l}\mathrm{G}_{\mathrm{c}} 90 / 20 \\
\mathrm{G}_{\mathrm{c}} 90 / 10 \\
\mathrm{G}_{\mathrm{c}} 90 / 15 \\
\mathrm{G}_{\mathrm{A}} 90 \\
\mathrm{G}_{\mathrm{A}} 90\end{array}$ \\
\hline 2. & $\begin{array}{l}\text { fine particle content: } \\
\text { - sort } 4 / 8 \\
\text { - sort } 0 / 4 \text { crushed sand } \\
\text { - sort } 0 / 4 \text { natural sand }\end{array}$ & $\begin{array}{l}\mathrm{f}_{0,5} \\
\mathrm{f}_{10} \\
\mathrm{f}_{3}\end{array}$ \\
\hline 3. & quality of fine particles (amount of blue) & $\mathrm{VB}_{\mathrm{F}} 10$ \\
\hline 4. & $\begin{array}{l}\text { shape of coarse aggregate: } \\
\text { - shape coefficient sort } 16 / 25 \\
\text { - shape coefficient sort } 8 / 16 \\
\text { - shape coefficient sort } 4 / 8 \\
\text { - flattening coefficient sort } 16 / 25 \\
\text { - flattening coefficient sort } 8 / 16 \\
\text { - flattening coefficient sort } 4 / 8\end{array}$ & $\begin{array}{l}\mathrm{SI}_{15} \\
\mathrm{SI}_{15} \\
\mathrm{SI}_{25} \\
\mathrm{~A}_{10} \\
\mathrm{~A}_{15} \\
\mathrm{~A}_{15}\end{array}$ \\
\hline 5. & coarse aggregate fragmentation resistance (Los Angeles) & $\mathrm{LA}_{30}$ \\
\hline 6. & wear resistance (Micro Deval) & $\mathrm{M}_{\mathrm{DE}} 15$ \\
\hline 7. & $\begin{array}{l}\text { granules volumic mass: } \\
\text { - absolute volumic mass }-\rho_{\mathrm{a}}\left(\mathrm{Mg} / \mathrm{m}^{3}\right) \\
\text { - sort } 16 / 25 \\
\text { - sort } 8 / 16 \\
\text { - sort } 4 / 8 \\
\text { - sort } 2 / 4 \\
\text { - real volumic mass determined by drying in oven }-\rho_{\mathrm{rd}}\left(\mathrm{Mg} / \mathrm{m}^{3}\right) \\
\text { - sort } 16 / 25 \\
\text { - sort } 8 / 16 \\
\text { - sort } 4 / 8 \\
\text { - sort } 2 / 4 \\
\text { - real volumic mass determined on saturated dry surface }-\rho_{\mathrm{ssd}} \\
\left(\mathrm{Mg} / \mathrm{m}^{3} \text { ) }\right. \\
\text { - sort } 16 / 25 \\
\text { - sort } 8 / 16 \\
\text { - sort } 4 / 8 \\
\text { - sort } 2 / 4 \\
\text { - the coefficient of water absorption after immersion for } 24 \text { hours - } \\
\mathrm{WA}_{24}(\%) \\
\text { - sort } 16 / 25 \\
\text { - sort } 8 / 16 \\
\text { - sort } 4 / 8\end{array}$ & $\begin{array}{l}2.765 \\
2.722 \\
2.514 \\
2.69 \\
2.698 \\
2.675 \\
2.443 \\
2.555 \\
\\
2.705 \\
2.692 \\
2.471 \\
2.605\end{array}$ \\
\hline
\end{tabular}


ROMANIAN JOURNAL

\section{OF TRANSPORT INFRASTRUCTURE}

Carmen Răcănel, Mihai Dicu, Ştefan Marian Lazăr, Adrian Burlacu, Asphalt mixtures with limestone aggregate for base layer

\begin{tabular}{|c|l|l|}
\hline & \multicolumn{1}{|c|}{- sort $2 / 4$} & \\
\hline 8. & water absorption: & \\
& - sort $16 / 25$ & $\mathrm{WA}_{24} 1$ \\
& - sort $8 / 16$ & $\mathrm{WA}_{24} 1$ \\
& - sort $4 / 8$ & $\mathrm{WA}_{24} 2$ \\
& - sort $2 / 4$ & $\mathrm{WA}_{24} 2$ \\
\hline 9. & resistance to freeze/thaw & $\mathrm{F}_{1}$ \\
\hline
\end{tabular}

Table 2. Characteristics of aggregates according to SR 667

\begin{tabular}{|c|c|c|c|}
\hline $\begin{array}{l}\text { No. } \\
\text { crt. }\end{array}$ & Characteristic & $\begin{array}{c}\text { Result } \\
\text { Category }\end{array}$ & $\begin{array}{l}\text { Conditions of } \\
\text { admissibility }\end{array}$ \\
\hline 1. & $\begin{array}{l}\text { Granules containing that: } \\
\text { - remains on the upper sieve, } \\
\text { \%max: } \\
\text { sort } 16 / 25 \\
\text { sort } 8 / 16 \\
\text { sort } 4 / 8 \\
\text { sort } 0 / 4 \text { crushed sand } \\
\text { sort } 0 / 4 \text { natural sand } \\
\text { - pass by lower sieve, } \\
\% \text { max: } \\
\text { sort } 16 / 25 \\
\text { sort } 8 / 16 \\
\text { sort } 4 / 8 \\
\text { sort } 0 / 4 \text { crushed sand } \\
\text { sort } 0 / 4 \text { natural sand }\end{array}$ & $\begin{array}{l}0 \% \\
0.4 \% \\
0.77 \% \\
2.55 \% \\
0.55 \% \\
\\
\\
17.95 \% \\
6.75 \% \\
12.83 \% \\
- \\
-\end{array}$ & $5 \%$ \\
\hline 2. & $\begin{array}{l}\text { Los Angeles resistance: } \\
\text { - sort } 16 / 25 \\
\text { - sort } 8 / 16 \\
\text { - sort } 4 / 8\end{array}$ & $\begin{array}{l}26.29 \% \\
21.10 \% \\
26.28 \%\end{array}$ & $\begin{array}{l}\text { - class A: } \\
\text { max. } 18 \% \\
\text { - class B: } \\
\text { max. } 20 \% \\
\text { - class C: } \\
\text { max. } 24 \%\end{array}$ \\
\hline 3. & $\begin{array}{l}\text { crushing resistance by dry } \\
\text { compression }\end{array}$ & $\begin{array}{l}\mathrm{SZ}_{18} \\
\text { according } \\
\mathrm{SR} 13043\end{array}$ & - \\
\hline 4. & $\begin{array}{l}\text { resistance to repeated action } \\
\text { of sodium sulphate, } 5 \text { cycles: } \\
\text { - sort } 16 / 25 \\
\text { - sort } 8 / 16\end{array}$ & $\begin{array}{l}15.20 \% \\
19.83 \%\end{array}$ & $\max .3 \%$ \\
\hline 5. & activity coefficient & 3.03 & $\max .2 .0$ \\
\hline
\end{tabular}

Studying the results obtained in Table 2, according to romanian standard, it can be said that aggregates sort 16/25 and 4/8 not fulfilling the condition of admissibility for the content of granules passing through the lower sieve. Also, 
none of sorts does not meet the Los Angeles resistance condition and resistance to repeated action of sodium sulphate.

In the case of crushed sand, activity coefficient exceeds the maximum value provided in the standard.

\section{ADHESIVENESS}

In order to establish the adhesion it was determined the affinity of aggregate with bituminous binders by two methods: spectrophotometer method and static method. It has been used a bitumen OMV 50/70 and a bitumen additivated OMV 50/70 plus. The results obtained are presented in Table 3.

Table 3. The affinity with bituminous binders according to SR 7970 and SR EN 13043

\begin{tabular}{|c|c|c|c|}
\hline $\begin{array}{l}\text { No. } \\
\text { crt. }\end{array}$ & Characteristic & Result declared & $\begin{array}{c}\text { Conditions of admissibility } \\
\text { according to SR } 7970\end{array}$ \\
\hline \multicolumn{4}{|c|}{ Spectrophotometer method } \\
\hline 1. & $\begin{array}{l}\text { Affinity with bitumen } \\
\text { OMV 50/70 }\end{array}$ & $56.7 \%$ & \multirow{2}{*}{$\begin{array}{l}\qquad \min .80 \% \\
\text { for technique class of roads: I - II } \\
\text { for technique category of streets: I -II }\end{array}$} \\
\hline 2. & $\begin{array}{l}\text { Affinity with bitumen } \\
\text { OMV 50/70 plus } \\
\text { (additivated) }\end{array}$ & $63.3 \%$ & \\
\hline \multicolumn{4}{|c|}{ Static method } \\
\hline 1. & $\begin{array}{l}\text { Affinity with bitumen } \\
\text { OMV 50/70 }\end{array}$ & $\begin{array}{l}35 \text { particles with } \\
\text { poor coated among } \\
150\end{array}$ & - \\
\hline
\end{tabular}

From the study of results from Table 3 it is observed that the requirement of minimum adhesion corresponding to the romanian standard SR 7970 is not fulfilled either for simply bitumen 50/70, or for additivated bitumen 50/70 plus when applying romanian method with spectrophotometer.

Regarding the interpretation of the result obtained by the static method set out in european standard SR EN 12697-11, there are no conditions of admissibility. Furthermore, the european standard SR EN 13043 provides for the determination of affinity with binder of the aggregate only the declaration of the result obtained according to SR EN 12697-11, there were no categories of results.

An adhesion study of bituminous binder to limestone aggregate from Hoghiz quarry was performed by LIETA Laboratory (SC POLL CHIM SA). There have been considered four types of bitumen: 70/100 Poland, 70/100 
MOL, 50/70 MOL and 50/70 LUKOIL BOURGAS and two adhesive agents ADETEN 02T-100 and 02T-200. The values obtained on bitumen additivated 70/100 MOL, 50/70 MOL, 50/70 LUKOIL BOURGAS corresponded to the minimum adhesion requirement according to SR 7970 ( $\mathrm{min} .75 \%$, for the base layer).

In the adhesion case of bitumen OMV 50/70 to limestone aggregate, additional study is necessary to determine the type of additive recommended to be used.

\section{ASPHALT MIXTURE RECIPE DETERMINATION FOR BASE LAYER}

Was chosen to design both the Marshall method and the volumetric design method (to gyratory compactor), a recipe of asphalt mixture for base layer, type AB 2, according to the standard SR 7970.

The recipe design by the Marshall method consists in selecting the optimum percentage of bitumen based on values obtained for Marshall stability and creep, and for apparent density.

Volumetric design consists in selecting an aggregate granulometric curve and binder, to determine the granularity and the percentage of bitumen that satisfy the criteria specified for the volume of the mixture goals, goals in aggregate mixture and goals filled with bitumen.

Figure 1 presents the granulometric curves of mixtures proposed and also their placing within the granulometric limits imposed by the standard SR 7970. and $5 \%$.

The percentages of bitumen considered for the study were: $4 \%, 4.5 \%$

Design of recipe by the volumetric method was performed for computing traffic volume of $0.21-2.1$ m.o.s. $115 \mathrm{kN}$ - medium traffic $(0.2-0.3$ m.o.s. $)$, heavy traffic $(0.3-1.0$ m.o.s. $)$ and very heavy traffic $(1.0-2.1$ m.o.s. $)$ according to the norm CD 155.

From studying the results obtained by the two methods of design, shall be determined that the recipe $\mathrm{AB} 2$ (I) with $4.5 \%$ bitumen is one that satisfies the requirement regarding to the goals volume in the compacted mixture. 
ROMANIAN JOURNAL

\section{OF TRANSPORT INFRASTRUCTURE}

Carmen Răcănel, Mihai Dicu, Ştefan Marian Lazăr, Adrian Burlacu, Asphalt mixtures with limestone aggregate for base layer

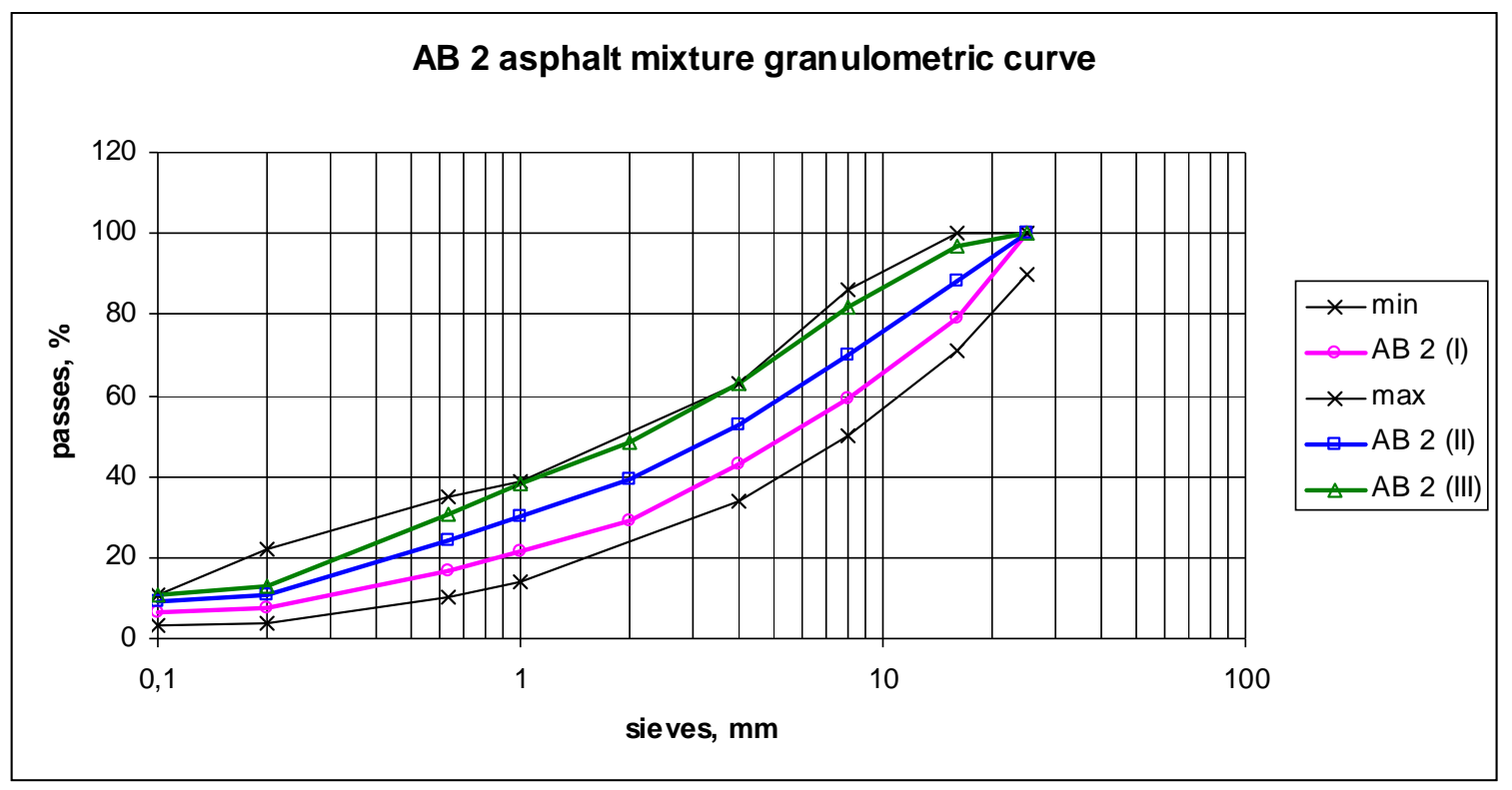

Figure 1. Granulometric curves considered

\section{TESTS ON ASPHALT MIXTURE DESIGNED FOR BASE LAYER, ACCORDING TO SR 7970}

In accordance with SR 7970, in the laboratory obtained results on AB2 recipe designed in laboratory are presented in Table 4.

Table 4. Characteristics according to SR 7970

\begin{tabular}{|c|c|c|c|}
\hline $\begin{array}{l}\text { No. } \\
\text { crt. }\end{array}$ & Characteristic & Result & $\begin{array}{c}\text { Conditions of admissibility according } \\
\text { to SR } 7970\end{array}$ \\
\hline \multicolumn{4}{|c|}{ Characteristics on cylindrical specimens } \\
\hline 1 & Stability to $60^{\circ} \mathrm{C}, \mathrm{kN}$ & 9.85 & $\begin{array}{l}\min .5 .5 \text { (roads of technique class I-III) } \\
\text { min. } 5.0 \text { (roads of technique class IV-V) }\end{array}$ \\
\hline 2 & Flow index, $\mathrm{mm}$ & 3.6 & $\begin{array}{l}1.5-3.5 \text { (roads of technique class I-III) } \\
1.5-4.0 \text { (roads of technique class IV-V) }\end{array}$ \\
\hline 3 & Apparent density, $\mathrm{kg} / \mathrm{m}^{3}$ & 2327 & min. 2200 \\
\hline 4 & Water absorption, \% vol. & 5.50 & $2 \ldots 8$ \\
\hline \multicolumn{4}{|c|}{ Characteristics on cubical specimens } \\
\hline 1 & $\begin{array}{l}\text { Compressive strength to } \\
22^{\circ} \mathrm{C}, \mathrm{N} / \mathrm{mm}^{2}\end{array}$ & 3.05 & $\min .2 .5$ \\
\hline 2 & $\begin{array}{l}\text { Reduction of compressive } \\
\text { strength to } 22^{\circ} \mathrm{C} \text {, after } 28 \\
\text { days of storage in water, } \%\end{array}$ & 26.56 & $\max .30$ \\
\hline 3 & Apparent density, $\mathrm{kg} / \mathrm{m}^{3}$ & 2274 & $\min .2150$ \\
\hline 4 & Water absorption, \% vol. & 7.47 & $2 \ldots 10$ \\
\hline
\end{tabular}


ROMANIAN JOURNAL

\section{OF TRANSPORT INFRASTRUCTURE}

From the study of the obtained results it follows that all the physicomechanical properties of the $\mathrm{AB} 2$ asphalt mixture designed in Laboratory of Roads from TUCEB, complies with the requirements of the romanian standard SR 7970.

\section{TESTS ON ASPHALT MIXTURES DESIGNED FOR BASE LAYER, ACCORDING TO SR EN 13108-1}

According to SR EN 13108-1 are required to determine the following characteristics: granulometry, volume of goals, stiffness modulus, resistance to permanent deformation, resistance to fatigue. Laboratory results are presented in Table 5.

Table 5. Characteristics according to SR EN 13108-1

\begin{tabular}{|c|c|c|c|}
\hline $\begin{array}{l}\text { No. } \\
\text { crt. }\end{array}$ & Characteristic & Result & $\begin{array}{c}\text { Conditions of } \\
\text { admissibility / Category } \\
\text { according to } \\
\text { SR EN 13108-1 }\end{array}$ \\
\hline 1 & Granulometry & $\begin{array}{l}\text { passing through the sieve } \\
\text { of } 31.5 \mathrm{~mm}: 100 \% \\
\text { passing through the sieve } \\
\text { of } 2 \mathrm{~mm}: 29.30 \% \\
\text { passing through the sieve } \\
\text { of } 0.063 \mathrm{~mm}: 4.78 \%\end{array}$ & $\begin{array}{l}\text { passing through the sieve } \\
\text { of } 31.5 \mathrm{~mm}: 90-100 \% \\
\text { passing through the sieve } \\
\text { of } 2 \mathrm{~mm}: 10-50 \% \\
\text { passing through the sieve } \\
\text { of } 0.063 \mathrm{~mm}: 0-11 \%\end{array}$ \\
\hline 2 & $\begin{array}{l}\text { Volume of goals to } 75 \\
\text { gyration, } \%\end{array}$ & 7.4 & $\begin{array}{l}\mathrm{V}_{\max 8.0} \\
\mathrm{~V}_{\min 6.0} \\
\end{array}$ \\
\hline 3 & $\begin{array}{l}\text { Resistance to permanent } \\
\text { deformation: } \\
\text { - rut depth, } \% \\
\text { - rutting slope, } \mathrm{mm} / 1000 \\
\text { cycles }\end{array}$ & $\begin{array}{l}7.10 \\
0.175 \\
\end{array}$ & $\begin{array}{l}\text { PRD }_{\text {AIR } 9.0} \\
\text { WTS }_{\text {AIR 5.0 }} \\
\end{array}$ \\
\hline 4 & Bitumen content, $\%$ & 4.5 & $\mathrm{~B}_{\min 4.4}$ \\
\hline 5 & Marshall stability, kN & 9.85 & $\begin{array}{l}S_{\min 7.5} \\
S_{\max 10}\end{array}$ \\
\hline 6 & Flow index, $\mathrm{mm}$ & 3.6 & $\mathrm{~F}_{4}$ \\
\hline 7 & $\begin{array}{l}\text { Stability/creep ratio } \\
\mathrm{kN} / \mathrm{mm}\end{array}$ & 2.74 & $\mathrm{Q}_{\min 2.5}$ \\
\hline 8 & $\begin{array}{l}\text { Volume of goals filled } \\
\text { with bitumen to } 75 \\
\text { gyration, } \%\end{array}$ & 43.8 & $\begin{array}{l}\mathrm{VFB}_{\min \mathrm{NR}} \\
\mathrm{VFB}_{\max } 50\end{array}$ \\
\hline 9 & $\begin{array}{l}\text { Volume of goals in } \\
\text { aggregate mixture to } 75\end{array}$ & 13.16 & $\mathrm{VMA}_{\min 12}$ \\
\hline
\end{tabular}


ROMANIAN JOURNAL

\section{OF TRANSPORT INFRASTRUCTURE}

Carmen Răcănel, Mihai Dicu, Ştefan Marian Lazăr, Adrian Burlacu, Asphalt mixtures with limestone aggregate for base layer

\begin{tabular}{|c|c|c|c|}
\hline & gyration, \% & & \\
\hline 10 & $\begin{array}{l}\text { Volume of goals to } 10 \\
\text { gyration, \% }\end{array}$ & 14.2 & $\mathrm{~V} 10 \mathrm{G}_{\min } 14$ \\
\hline 11 & $\begin{array}{l}\text { Stiffness, MPa } \\
\text { - IT-CY } \\
\text { - 4PB-PR }\end{array}$ & $\begin{array}{l}3416 \\
6647 \\
\end{array}$ & $\begin{array}{l}S_{\min 2800} \\
S_{\max 7000} \\
S_{\min 5500} \\
S_{\max 7000}\end{array}$ \\
\hline 12 & $\begin{array}{l}\text { Resistance to permanent } \\
\text { deformation - triaxial } \\
\text { compression test: } \\
\text { - permanent deformation, } \\
\mu \mathrm{m} / \mathrm{m} \\
\text { - strain rate, } \mu \mathrm{m} / \mathrm{m} / \text { cycle }\end{array}$ & $\begin{array}{l}5617 \\
0.028\end{array}$ & $f_{\text {cmax } 0.2}$ \\
\hline 13 & $\begin{array}{l}\text { Resistance to fatigue, } \mu \mathrm{m} \\
\text { (4PB-PR) }\end{array}$ & 40 & $\varepsilon_{6-\mathrm{NR}}$ \\
\hline
\end{tabular}

\section{PRODUCT SHEET}

According to SR EN 13108-1 was prepared the product sheet for the AB 2 asphalt mixture designed in laboratory, considering the general and empirical requirements (Table 6) and the general and fundamental requirements (Table 7).

Table 6. Product sheet for AB 2 asphalt mixture general requirements and empirical requirements

\section{SR EN 13108-1}

Asphalt Concrete for roads and other trafficked areas (Béton d'asphalte pour les routes et autres zones de circulation)

AC 31.5 base 50/70

General requirements and empirical requirements

Volume of goals

\begin{tabular}{|l|r|}
\hline- maximum & $\mathrm{V}_{\max 8.0}(8.0 \%)$ \\
- minimum & $\mathrm{V}_{\min 6.0}(6.0 \%)$ \\
\hline
\end{tabular}

Volume of goals filled with bitumen

\begin{tabular}{|c|c|}
\hline $\begin{array}{l}\text { - minimum } \\
\text { - maximum }\end{array}$ & $\begin{array}{r}\mathrm{VFB}_{\min \mathrm{NR}}(\mathrm{NR}) \\
\mathrm{VFB}_{\max } 50(50 \%)\end{array}$ \\
\hline Volume of goals in aggregate mixture & $\mathrm{VMA}_{\min 12}(12 \%)$ \\
\hline Volume of goals to 10 gyration & $\mathrm{V} 10 \mathrm{G}_{\min 14}(14 \%)$ \\
\hline Mixture temperature & $140{ }^{\circ} \mathrm{C}-180^{\circ} \mathrm{C}$ \\
\hline
\end{tabular}


ROMANIAN JOURNAL

\section{OF TRANSPORT INFRASTRUCTURE}

Carmen Răcănel, Mihai Dicu, Ştefan Marian Lazăr, Adrian Burlacu, Asphalt mixtures with limestone aggregate for base layer

Aggregate granulometry, passes

\begin{tabular}{|l|r|}
\hline $31.5 \mathrm{~mm}$ & $100 \%$ \\
\hline $25 \mathrm{~mm}$ & $100 \%$ \\
\hline $16 \mathrm{~mm}$ & $79 \%$ \\
\hline $8 \mathrm{~mm}$ & $59 \%$ \\
\hline $4 \mathrm{~mm}$ & $43 \%$ \\
\hline $2 \mathrm{~mm}$ & $29.30 \%$ \\
\hline $1 \mathrm{~mm}$ & $21.54 \%$ \\
\hline $0.63 \mathrm{~mm}$ & $16.79 \%$ \\
\hline $0.2 \mathrm{~mm}$ & $7.35 \%$ \\
\hline $0.1 \mathrm{~mm}$ & $6.38 \%$ \\
\hline $0.063 \mathrm{~mm}$ & $4.78 \%$ \\
\hline
\end{tabular}

\begin{tabular}{|l|l|}
\hline Bitumen content & $\mathrm{B}_{\min 4.4}(4.4 \%)$ \\
\hline
\end{tabular}

Marshall values

Marshall stability minimum

Marshall stability maximum

Flow index

Stability/creep ratio

\begin{tabular}{r|}
$\mathrm{S}_{\min 7.5}(7.5 \mathrm{kN})$ \\
$\mathrm{S}_{\max 10}(10 \mathrm{kN})$ \\
$\mathrm{F}_{4}(4 \mathrm{~mm})$ \\
$\mathrm{Q}_{\min 2.5}(2.5 \mathrm{kN} / \mathrm{mm})$ \\
\hline
\end{tabular}

Resistance to permanent deformation (small equipment, in air)

Rut depth

Rutting slope

$\mathrm{PRD}_{\text {AIR } 9.0}(9.0 \%)$

$\mathrm{WTS}_{\text {AIR 5.0 }}(5 \mathrm{~mm})$

Table 7. Product sheet for AB 2 asphalt mixture general requirements and fundamental requirements

\section{SR EN 13108-1}

Asphalt Concrete for roads and other trafficked areas

(Béton d'asphalte pour les routes et autres zones de circulation)

AC 31.5 base 50/70

General requirements and fundamental requirements

Volume of goals

\begin{tabular}{|c|c|}
\hline $\begin{array}{l}\text { - maximum } \\
\text { - minimum }\end{array}$ & $\begin{array}{l}\mathrm{V}_{\max 8.0}(8.0 \%) \\
\mathrm{V}_{\min 6.0}(6.0 \%)\end{array}$ \\
\hline Mixture temperature & $140{ }^{\circ} \mathrm{C}-180{ }^{\circ} \mathrm{C}$ \\
\hline \multicolumn{2}{|c|}{ Aggregate granulometry, passes } \\
\hline $31.5 \mathrm{~mm}$ & $100 \%$ \\
\hline $25 \mathrm{~mm}$ & $100 \%$ \\
\hline
\end{tabular}


ROMANIAN JOURNAL

\section{OF TRANSPORT INFRASTRUCTURE}

Carmen Răcănel, Mihai Dicu, Ştefan Marian Lazăr, Adrian Burlacu, Asphalt mixtures with limestone aggregate for base layer

\begin{tabular}{|c|c|}
\hline $16 \mathrm{~mm}$ & $79 \%$ \\
\hline $8 \mathrm{~mm}$ & $59 \%$ \\
\hline $4 \mathrm{~mm}$ & $43 \%$ \\
\hline $2 \mathrm{~mm}$ & $29.30 \%$ \\
\hline $1 \mathrm{~mm}$ & $21.54 \%$ \\
\hline $0.63 \mathrm{~mm}$ & $16.79 \%$ \\
\hline $0.2 \mathrm{~mm}$ & $7.35 \%$ \\
\hline $0.1 \mathrm{~mm}$ & $6.38 \%$ \\
\hline $0.063 \mathrm{~mm}$ & $4.78 \%$ \\
\hline Bitumen content & $\mathrm{B}_{\min 4.4}(4.4 \%)$ \\
\hline \multicolumn{2}{|l|}{ Stiffness, IT-CY } \\
\hline - minimum & $\mathrm{S}_{\min 2800}(2800 \mathrm{MPa})$ \\
\hline - maximum & $\mathrm{S}_{\max 7000}(7000 \mathrm{MPa})$ \\
\hline \multicolumn{2}{|l|}{ Stiffness, 4PB-PR } \\
\hline - minimum & $\mathrm{S}_{\min 5500}(5500 \mathrm{MPa})$ \\
\hline - maximum & $\mathrm{S}_{\max 7000}(7000 \mathrm{MPa})$ \\
\hline \multicolumn{2}{|c|}{ Resistance to permanent deformation (triaxial compression) } \\
\hline Strain rate & $\mathrm{f}_{\mathrm{cmax} 0.2}(0.2 \mu \mathrm{m} / \mathrm{m} / \mathrm{ciclu})$ \\
\hline Resistance to fatigue, $4 \mathrm{~PB}-\mathrm{PR}$ & $\varepsilon_{6-\mathrm{NR}}$ \\
\hline
\end{tabular}

\section{CONCLUSIONS}

Conclusions drawn from this study are presented below.

- It was designed in the laboratory, by Marshall design method and volumetric design method (with gyratory compactor), a recipe of asphalt mixture for base layer, with limestone aggregate from Hoghiz quarry and bitumen OMV 50/70.

- Considering that there were available crushed natural aggregates chippings sort $4 / 8,8 / 16,16 / 25$, crushing sand sort $0 / 4$ and natural sand $0 / 4$, the proposed granulometric curves for asphalt mixture from the base layer fits in the technique class I for roads/highways and the technique class I for streets, according to SR 7970.

- Requirements imposed to the volumetric design of asphalt mixture correspond to one computing traffic volume of $0.21-2.1$ m.o.s. $115 \mathrm{kN}$ medium traffic, heavy traffic and very heavy traffic according to the normative CD 155. 
ROMANIAN JOURNAL

\section{OF TRANSPORT INFRASTRUCTURE} as follows:

- The final recipe of asphalt mixture $\mathrm{AB} 2$ considered optimal variant is

- crushed limestone 16-25

- crushed limestone 8-16

- crushed limestone 4-8

- crushing limestone $0-4$

- river sand 0-4

- filler

- bitumen
$20.06 \%$

$19.1 \%$

$15.28 \%$

$22.92 \%$

$15.28 \%$

$2.87 \%$

$4.5 \%$

- Designed recipe is valid only for the materials studied; if either aggregate or bitumen changes, then is necessary a new laboratory study.

- The limestone aggregates not fulfilling the condition of Los Angeles resistance, of resistance to repeated action of sodium sulphate and the requirement imposed for the activity coefficient; thus not having the resistances necessary, shall be used with caution in asphaltic mixture of pavement layer only after the specialized laboratory study.

- Aggregates not fulfilling the condition of adhesivity with simple binder OMV 50/70 and with additivated binder OMV 50/70 plus; so for the use of binder OMV 50/70 in the asphalt mixture will be carried out separated an adhesivity study, in order to increase the aggregate adhesion to binder. However it is specified that adhesion of other bituminous binders to limestone aggregate from the Hoghiz quarry is met in case of using the adhesivity agents. Therefore, using this type of aggregate must be done only in the conditions recommended by a specialized laboratory for each work separately.

- Due to unsatisfactory behavior in the presence of water (the test of determining the maximum specific gravity) should be pay particular attention to such asphalt mixtures eliminating as possible presence of water in asphalt layer, the resistances of such asphalt mixtures realized with limestone aggregates being modified in a negative way; attention will be given to the sealing of the realised layer.

- According to the romanian standard SR 7970 the asphalt mixture designed, AB 2, qualify as requirements for a technical class road IV - V.

- According to the european standard SR EN 13108-1, was drawn the product sheet for the asphalt mixture labeled as AC 31.5 base 50/70 for both general and empirical requirements and for general and fundamental requirements. 


\section{ROMANIAN JOURNAL OF TRANSPORT INFRASTRUCTURE}

- The $\mathrm{AB} 2$ asphalt mixture made with the limestone aggregates not present resistance to fatigue, therefore can be used only in base layers for technical class roads IV or V (roads with light traffic) and normal duration of operation reduced.

- In order to obtain the solution approval (certification of material) is recommended the realization of an experimental section (according to the approval conditions) that will be supervised in operation for at least 1 year to evaluate the performances of $\mathrm{AB} 2$ asphalt mixture with limestone aggregates.

- It is recommended the continuation of this laboratory study by comparative analysis with an $\mathrm{AB} 2$ asphalt mixture with natural aggregates that fulfilling the requirements of the rules in force, that will be used as reference.

\section{REFERENCES}

[1]. "The use study of limestone aggregates made available by the beneficiary to the realization of asphalt mixtures for base layer", TUCEB Research Contract Research Center ROADS and AIRPORTS, no. 215/06.07.2011. 